Pamiętnik Literacki 2018, 2, s. 119-138

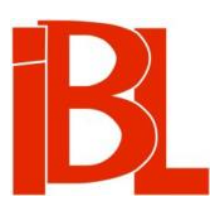

\title{
Rok 1836: Juliusz Słowacki pod piramidami
}

\author{
Adam Łukaszewicz
}


Pamiętnik Literacki CIX, 2018, z. 2, PL ISSN 0031-0514

DOI: $10.18318 / \mathrm{pl} .2018 .2 .6$

ADAM ŁUKASZEWICZ Uniwersytet Warszawski

\section{ROK 1836: JULIUSZ SŁOWACKI POD PIRAMIDAMI*}

\section{Notatnik Słowackiego z podróży na Wschód}

Odnalezienie zaginionego notatnika Juliusza Słowackiego z podróży na Wschód podjętej w r. 1836 przyniosło prawdziwy renesans badań nad tą najważniejszą wyprawą w życiu młodego poety. Oznacza to również wzrost zainteresowania utworami „egipskimi” wieszcza. Dodajmy tu, że poza Polską naukowcy zajmujący się wojażami Europejczyków do Egiptu o Słowackim przeważnie w ogóle nie słyszeli, a tylko niekiedy wspominaja o Radziwille Sierotce i jego Hierosolymitana peregrinatio ${ }^{1}$.

Notatnik, po śmierci Słowackiego przechowany przez jego matkę, należał następnie do jego wuja, Teofila Januszewskiego, a później do Wiktora Sobieszczańskiego. Gdy ten ostatni zmarł, notatnik został pod koniec XIX w. sprzedany, wraz z niektórymi innymi rękopisami poety, Leopoldowi Méyetowi, po jego zaś śmierci (1912) znalazł się w zbiorach Ordynacji Krasińskich ${ }^{2}$. Był wprawdzie znany wydawcom i badaczom, ale nie doczekał się poważniejszego opracowania (istniejący od 1929 r. opis Manfreda Kridla zawiera niezbyt ścisłe interpretacje rysunków Słowackiego z Egiptu), ani osobnej publikacji. W roku 1939 notatnik wyekspediowano na wystawę do Krzemieńca, która miała być otwarta w 130 rocznicę urodzin wieszcza, 4 IX 1939. Zabytek ten trafił z Warszawy do Krzemieńca zapewne już w maju 1939. Jeszcze w czerwcu, przed końcem roku szkolnego, chciano (wedle ustnej relacji kustoszki wystawy) udostępnić pamiątki po Słowackim młodzieży szkolnej. Dzien 17 IX 1939 położył kres polskiemu życiu kulturalnemu w Krzemieńcu. W obliczu najazdu najcenniejsze eksponaty $\mathrm{z}$ wystawy trafiły, według tej samej relacji, do sejfu Liceum Krzemienieckiego; po rychłej śmierci jego dyrektora słuch o tym wyjątkowym dokumencie zaginął na długie lata. Notatnik Słowackiego po wojennych peregrynacjach odnalazł się niedawno w Bibliotece Państwowej

* Artykuł powstał w ramach projektu badawczego Odnaleziony raptularz Juliusza Stowackiego z podróży na Wschód jako romantyczne dzieło synkretyczne oraz źródło literackie i ikonograficzne do badań nad historia i kultura XIX wieku, finansowanego z grantu NCN: NCN 2014/15/B/H52/01360 (kierownik projektu: prof. dr hab. Maria Kalinows ka).

$1 \quad$ Książę Mikołaj Krzysztof Radziwiłł (1549-1616) odwiedził m.in. Egipt w r. 1583 i pozostawił nader ciekawy opis tej podróży, Hierosolymitana peregrinatio, wydany w 1601 roku.

2 Wiadomości o historii notatnika do czasu jego włączenia do Bibl. Krasińskich zawdzięczam prof. Zbigniewowi Przychodniakowi. 
w Moskwie ${ }^{3}$ i stał się przedmiotem prac zespołu badawczo-edytorskiego kierowanego przez Marię Kalinowską, do którego należy także autor niniejszego tekstu. Zespół ten przyjął na określenie owego notatnika termin „raptularz”, który wszakże wydaje mi się nazbyt archaiczny. Słowacki był bowiem poetą na wskroś nowoczesnym. Jakkolwiek nazwiemy sam przedmiot, ważna jest jego zawartość tekstowa. Raptularz ma formę zeszytu, z kartkami o złoconych brzegach, oprawionego (zapewne w czasach, gdy znajdował się w zbiorach Biblioteki Krasińskich) w ciemnozielone okładki $z$ wytłoczonym złoconym napisem: Rękopisma Iuliusza Słowackiego. Zdaniem Zbigniewa Przychodniaka, oprawa ta powstała po r. 1912, a przed r. 1931, kiedy to korzystał z rękopisu Leon Piwiński. Odnoszę wrażenie, iż kształt liter na okładce wskazuje na powstanie napisu wkrótce po dacie wejścia raptularza do zbiorów Ordynacji Krasińskich, zapewne jeszcze przed pierwszą wojną światową. Utwory związane z pobytem Słowackiego w Egipcie zajmują w tym zeszycie karty od 34r do 46r, zawierające zarówno wiersze, jak i notatki. Owe wiersze znane sa jako [Listy poetyckie z Egiptu] - składają się na nie teksty: Do Teofila Januszewskiego, Piramidy, Na szczycie piramid, List do Aleksandra H., Z Nilu-do... Kartę z rękopisem Hymnu („Smutno mi Boże...”) wyrwał sam poeta, by ofiarować ją Kornelowi Ujejskiemu. Ponadto na dalszych kartach zeszytu znajdujemy dość długą serię rysunków ołówkiem, powstałych niewątpliwie w czasie podróży. Wiele z nich przedstawia rozmaite miejsca widziane przez Słowackiego w Egipcie. Rysunki te maja przeważnie charakter pośpiesznych szkiców, sporządzonych, by utrwalić obrazy i wrażenia. Zdradzaja jednak talent oraz pewne wykształcenie plastyczne (Słowacki pobierał w latach szkolnych lekcje rysunku).

Pozostawiając innym badaczom wchodzacym w skład zespołu przygotowujacego edycję raptularza szczegóły dotyczące tego rewelacyjnego źródła, zajmiemy się tu jedynie pewnymi aspektami podróży Słowackiego po Egipcie. Przedstawione tu uwagi nie odnoszą się wyłącznie do wspomnianego notatnika, ale opierają się głównie na publikowanych utworach wieszcza.

Pobyt Słowackiego w Egipcie w r. 1836 w ramach jego wielkiej wschodniej peregrynacji (1836-1837) był przedmiotem dość licznych opracowań, raczej czastkowych (w obrębie opisów całej podróży) niż monograficznych. Należy stwierdzić, że opracowania te nie są wolne od błędów i usterek, łatwo dostrzegalnych dla wnikliwego historyka zajmującego się starożytnym Egiptem. Dotyczy to także, ważnej skądinąd, monografii Ryszarda Przybylskiego ${ }^{4}$. Jan Stanisław Bystroń ${ }^{5}$, a za nim orientalista Jan Reychman ${ }^{6}$, oceniali „egipskie” wiersze Słowackiego jako rozczarowujące i najsłabsze w całym jego dorobku. Jest to ocena tendencyjna, wynikająca $z$ niepełnego i powierzchownego rozumienia treści tych utworów. Także pogląd, że powstały one w Italii, już po powrocie ze wschodniej podróży ${ }^{7}$, jest niesłuszny.

Zob. np. H. G ł ę b o c k i: Zaginiony raptularz Juliusza Stowackiego z podróży na Wschód (1836-1837) - odnaleziony po 70 latach $w$ zbiorach rosyjskich. „Pamiętnik Literacki” 2011, z. 2; Juliusza Stowackiego podróż na Wschód (odnaleziony - w Moskwie - raptularz wieszcza). „Arcana” 2011, nr 4.

$4 \quad$ R. Pr zy by ls ki, Podróż Juliusza Stowackiego na Wschód. Kraków 1982.

5 J. S. By s troń, Polacy w Ziemi Świętej, Syrii i Egipcie. Kraków 1930.

6 J. Rey ch ma n, „Rzucam się $w$ świat nieznajomy...” W: Podróżnicy polscy na Bliskim Wschodzie $w$ XIX $w$. Warszawa 1972, s. 120-121.

7 Zob. L. Lib er a, Juliusza Stowackiego podróż do Ziemi Świętej z Neapolu. Poznań 1993, s. 127. 
Przed kilku laty ukazał się interesujący artykuł poświęcony tym wierszom, ale i on nie przynosi rzeczowych objaśnień starożytniczych związanych z egipską przygodą wieszcza ${ }^{8}$.

\section{Podróż na Wschód}

Droga, która zaprowadziła Słowackiego - przez Paryż, Genewę i Neapol - aż nad Nil, miała swój początek 8 III 1831, kiedy przyszły wieszcz opuścił Warszawę i wyruszył via Wrocław do Drezna, nakłaniany do tego przez matkę, która obawiała się dla niego przykrych konsekwencji po przewidywanej przez nią klęsce powstania listopadowego. W liście do Salomei Bécu datowanym z Wrocławia 17 III 1831 Słowacki pisze: „Dopełniając woli kochanej Mamy, która aż nazbyt z moją chęcią zgadzała się, wyjechałem za granice [...]"9. Następnie udał się poeta do Paryża i Londynu i wreszcie - w grudniu 1832 - osiadł w Genewie.

W lutym 1836 Słowacki pojechał z Genewy do Marsylii i stamtąd do Włoch. Nie wiadomo, czy zdecydowałby się na wyprawę na Wschód, gdyby nie rzucili tej myśli dwaj znajomi Polacy. Przybyli oni do Neapolu na przełomie lipca i sierpnia 1836. Jeden $z$ nich zapewne pożyczył poecie pieniędzy na podróż (1000 rubli srebrem). Przybylski słusznie się domyśla, wbrew zdaniu Pawła Hertza ${ }^{10}$, że był to Aleksander Hołyński, młodzian 20-letni, współwłaściciel (wraz ze starszym bratem Stefanem) Krzyczewa w powiecie czernichowskim na kresach wschodnich (wówczas w cesarstwie rosyjskim). Stefan Hołyński, liczący sobie lat 24, był już w drodze na Wschód. Drugi pomysłodawca wyprawy to Zenon Brzozowski (1806-1887), zamożny ziemianin $z$ Podola. 5 lat później ożenił się $\mathrm{z}$ Elizą Zamoyska, wchodząc tym samym $\mathrm{w}$ powinowactwo nie tylko $\mathrm{z}$ teściem - ordynatem Stanisławem, ale i z księciem Adamem Czartoryskim, którego siostrzenica była wybranka ${ }^{11} .1000$ rubli srebrem była to suma bardzo znaczna, odpowiednik ponad 6600 złotych polskich, czyli około 3700 franków. Gdyby Słowacki pożyczył tę kwotę od Brzozowskiego, zapewne trudno by mu było zachowywać wobec wierzyciela i towarzysza podróży niechętny dystans, który charakteryzował stosunek poety do niego.

24 VIII 1836 Słowacki wyjechał z Neapolu do Grecji. Grecki etap podróży znaczyły późne echa filhellenizmu à la lord Byron. Europa Zachodnia nie była z początku zdecydowana, czy powinna popierać chwiejącą się Wysoką Portę, czy też, idąc za romantycznymi hasłami, dążyć do poszerzania państwa helleńskiego kosztem Turcji. Watpliwości nie miała za to Rosja, dla której młode państewko greckie było bastionem ortodoksji i koniem trojańskim u wrót Konstantynopola. Dodajmy przy okazji, że w szeregach armii rosyjskiej walczacej z polskim powstaniem byli także Grecy. Książę Georgios Muruzis (1804-1831), przedstawiciel arystokratycznego środowiska fanariotów ${ }^{12}$ i potomek wielkiego rodu hospodarskiego, poległ przy zdobywaniu Warszawy, jako zastępca dowódcy pułku huzarów gwardii, we wrześniu

Zob. M. J o n c a, Stowacki egipski. „Prace Literackie” nr 49 (2009).

J. Słow acki, Listy do matki. W: Dzieła. T. 11. Oprac. Z. Krzyżanowska. Wrocław 1949,

s. 11.

10 P. Hertz, Portret Stowackiego. Wyd. 2. Warszawa-Kraków 1950, s. 85.

11 Zob. Przybylski, op. cit., s. 128.

12 Fanarioci - potomkowie greckiej arystokracji, pozostałej w Imperium Osmańskim po podboju 
1831 i spoczywa na Cmentarzu Powazkowskim ${ }^{13}$. W okresie inwazji egipskiej pod wodzą Ibrahima baszy, który interweniował w Morei w r. 1824, wielkie mocarstwa zjednoczyły się w wysiłkach na rzecz ratowania zagrożonego państwa ottomańskiego i w 1827 r. zatopiły flotę egipska pod Navarino (dziś Pylos). W czasach pobytu Słowackiego w Grecji umacniało się niewielkie greckie królestwo pod berłem młodziutkiego Ottona z bawarskiej dynastii Wittelsbachów, która przekazała Grecji biało-niebieskie barwy jej flagi.

\section{Z Grecji do Aleksandrii}

$12 \mathrm{X} \mathrm{z}$ greckiej wyspy Syros wypłynął Słowacki ku egipskiej Aleksandrii. Pisał wcześniej do matki z Otranto 29 VIII 1836:

Nie rozumiesz zapewne, moja droga, co mię do takiej nakłoniło podróży - ja sam prawdziwie nie mogę sobie wytłumaczyć, dlaczego $\mathrm{z}$ takim smutnym zapałem rzucam się w świat nieznajomy, pełny niebezpieczeństw, gdy w Grecji rozboje, w Egipcie zaraza panuje ${ }^{14}$.

Nie ma zatem wątpliwości co do tego, że Słowacki u progu swej orientalnej przygody żywił niemało obaw. Zaraza, owszem, była. Zaczęła się przed podróżą poety do Egiptu. Europejczycy, zamieszkali już w dość znacznej liczbie w Kairze, przeważnie uciekli. Ci, co pozostali, stosowali rozmaite środki zapobiegawcze, których nieporadność może nam się dzisiaj wydać groteskowa: np. nakrywali się cerata, bo to jakoby miało chronić przed zachorowaniem ${ }^{15}$. Echo tego dramatu, jakże częstego w owych czasach ${ }^{16}$, zachowało się m.in. w dziele Johna Gardnera Wilkinsona Topography of Thebes. Autor pisze, że zamierzał pierwotnie wydrukować swą książkę w Aleksandrii, ale przeszkodziła w tym epidemia cholery i śmierć aleksandryjskiego drukarza ${ }^{17}$. Bezsilność wobec chorób epidemicznych była przyczyna panicznego lęku, który Słowacki podzielał, może i nie bez wpływu wiedzy wyniesionej z domu. Jego ojczym, August Bécu, uwieczniony przez Mickiewicza w Dziadach jako donosiciel rażony piorunem, który stopił judaszowe srebrniki, znajdujące się „w biurku, tuż u głów Doktora”" ${ }^{18}$, był zasłużonym pionierem szczepień ochronnych przeciw ospie na Wileńszczyźnie. Plotka, którą obrosła jego przypadkowa śmierć od pioruna w czasie drzemki przy otwartym oknie w upalny dzień 26 VIII 1824, musiała przysparzać wielu przykrości wdowie i pasierbowi.

Konstantynopola przez Turków w r. 1453, zamieszkali głównie w konstantynopolitańskiej dzielnicy Fanarion.

Zob. A. Łaj ta r, T. D e r d a, Epigrafik grecki na Powazkach. Epitafium księcia Georgiosa Muruzisa (1804-1831). W zb.: TIMAI. Studia poświęcone Profesorowi Włodzimierzowi Lengauerowi przez uczniów i młodszych kolegów z okazji Jego 60. urodzin. Red. A. Woli c ki. Warszawa 2009.

14 Słowacki, op. cit., s. 281.

15 Zob. R. Solé, L'Égypte, passion française. Paris 1997, s. 132.

16 Podobne epidemie powtarzały się jeszcze długo potem. Pół wieku po epidemii poprzedzającej pobyt Słowackiego, w r. 1883, cholera pojawiła się w Kairze. W jej zwalczaniu zasłużył się francuski lekarz i kolekcjoner D.-M. Fouquet (1850-1914).

17 J. G. Wilk in s o n, Topography of Thebes and General View of Egypt [...]. London 1835, s. V (Preface).

18 A. Mickiewicz, Dziadów część trzecia. W: Dzieła. Wyd. Narodowe. T. 3. Oprac. S. Pigoń. Warszawa 1953, s. 248. 
Ciekawość Orientu przemogła lęk przed zarazą. Wiersz Do Teofila Januszewskiego, datowany w Aleksandrii 22 X 1836, zawiera bardzo interesujące wyjaśnienie motywów podróży Słowackiego na Wschód:

Ja w nieznane uciekam krainy południa

Przed ścigającą myślą - i mrozami grudnia. [s. 139, w. 41-42] ${ }^{19}$

Ani słowa o jakichś mistycznych czy pielgrzymkowych motywacjach!

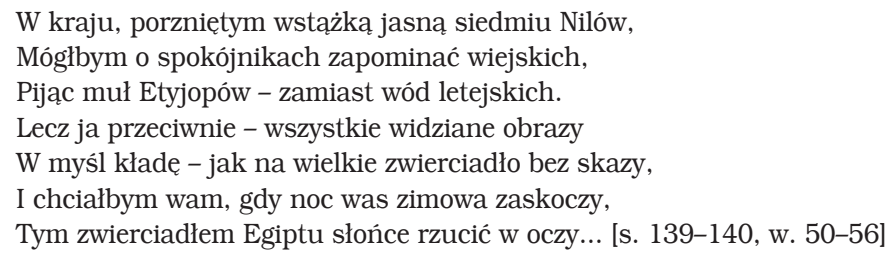

Opis podróży był zatem wcześniej zaplanowany i miał posłużyć bliskim poety jako swego rodzaju remedium na zimna i ponurą rzeczywistość krajową. W tę zapowiedź wkłada Słowacki elementy klasycznej erudycji: wzmiankę o siedmiu odnogach Nilu (dziś są tylko dwie) oraz o wylewie niosącym muł z Etiopii.

Tuż przed końcem podróży z Grecji do Egiptu powstał na morzu znany Hymn („Smutno mi Boże...”). Ale oto - jak czytamy w wierszu Do Teofila Januszewskiego:

„Ziemia” - i ziemia wyszła na morza błękicie,

Jak złocistego piasku - dziergany obrąbek. [s. 140, w. 58-59]

\section{U wrót Egiptu}

Pierwszym, co Słowackiemu nad ranem rzuciło się w oczy, gdy patrzył z morza, był aleksandryjski pałac Mohammeda Alego na przylądku Ras el-Tin:

Rzekłbyś, że biały siedzi na piaskach gołąbek

Przypatrując się sobie w zwierciadlanej fali,

A to był pałac wielki Mohameda-Ali -

Rzekłbyś, że przed nim resztki wieśniaczego płota

Sterczą - to była Ali-Mohameda flota - [s. 140, w. 60-64]

Słowacki razem z Brzozowskim zostali wkrótce przyjęci w tym pałacu przez Mohammeda Alego ${ }^{20}$. Jego flota kilka lat wcześniej wzięła udział w ekspedycji do Grecji, o czym poeta wspomina w pieśni IV Podróży do Ziemi Świętej z Neapolu ${ }^{21}$. Teraz widział tę flotę już odbudowaną po klęsce pod Navarino.

Władca Egiptu, Mohammed Ali, urodzony w r. 1769, był rówieśnikiem Napoleona i chyba nie mniej zręcznym od niego politykiem, choć miał znacznie skromniejsze pole do popisu. Ostatecznie jednak zapewnił sobie i założonej przez siebie

W ten sposób odsyłam do: J. Słow a cki, Wiersze. Nowe wydanie krytyczne. Oprac. J. Brzozowski, Z. Przy chodniak. Poznań 2005. Trzeba zaznaczyć, że tekst rękopisów zawartych w raptularzu jest niekiedy mniej lub bardziej odmienny.

20 Później jego wnętrze opisał M. Mann: Podróż na Wschód. T. 1. Kraków 1854, s. 53-54. Zob. Przybylski, op. cit., s. 220.

21 J. Słow a c ki, Podróż do Ziemi Świętej z Neapolu. W: Dzieła. T. 3 (Oprac. J. Pe1c), s. 36. 
dynastii niemal 150-letnie panowanie. Od roku 1805 był namiestnikiem Egiptu $\mathrm{z}$ ramienia sułtana tureckiego, a od 1811 niepodzielnie tam władał. Jako wicekról (chedyw), panujacy pod nominalnym protektoratem sułtana, rozwijał i europeizował Egipt, posługując się całą rzeszą cudzoziemskich doradców i pracowników. Do pomników kultury kraju faraonów nie przywiązywał szczególnej wagi, pozostawiając rodzącą się archeologię (i grabież zabytków) pozbawionym skrupułów cudzoziemcom. Pomimo klęski poniesionej w Grecji, Mohammed Ali - jak niegdyś Ptolemeusze - podjął wkrótce wyprawę do Syrii, należącej do Imperium Osmańskiego, pragnąc umocnić swą władzę i powiększyć podległe mu terytorium. Sułtan był zagrożony i Europa, tak jak w r. 1827, udzieliła Turcji pomocy. Egipt został zmuszony do podpisania układu, w którym wyrzekał się dalszej ekspansji. Jednak i to nie przeszkodziło Mohammedowi Alemu w umacnianiu władzy i w odbudowie floty, widzianej potem przez Słowackiego na redzie Aleksandrii. Po klęsce powstania listopadowego polscy wojskowi działali w armii Mohammeda Alego, podejmującego mimo niepowodzeń dzieło unowocześnienia i umocnienia Egiptu. Niektórzy przybywali do tego kraju w poszukiwaniu perspektyw współpracy, jak generał Henryk Dembiński (1791-1864) ${ }^{22}$.

Wyjazdy Europejczyków do Egiptu stały się wówczas bardzo częstym zjawiskiem. Na Nilu mijały się liczne łodzie pasażerskie $z$ mieszkalnymi kabinami, w których zamożni Europejczycy z kontynentu oraz Anglosasi z obu brzegów Atlantyku podróżowali do piramid, świątyń i grobowców.

Słowacki dotarł do Aleksandrii 20 X 1836. Widać, że kalendarz jego podróży był przemyślany, poeta uniknął bowiem nieprzyjemnych upałów. Stanąwszy na lądzie zetknął się z natrętnymi oślarzami, którzy dali mu się we znaki, biorąc go jak pisze w wierszu Do Teofila Januszewskiego - za „Złotego [...] milorda” (s. 143, w. 88). Wygląda na to, że Słowacki, niezbyt zasobny, nie był skłonny do hojnego dawania bakszyszu. Kilka dni spędził poeta w zajeździe „Pod Złotym Orłem”. Już 22 X powstał - jak wspomniano - utwór zawierający pierwsze impresje aleksandryjskie, m.in. oddające lapidarnie szczególną aurę afrykańskiego brzegu.

Tak mi się ukazały afrykańskie brzegi

Smutne - obumarłymi południka śniegi

Zasypane pod nieba sklepionego łuną [s. 141, w. 73-75]

Konstatując „smutek tropików”, Słowacki wyprzedza Lévi-Straussa. „Obumarłe śniegi" to przenośnia, odnosząca się niewątpliwie do białych piasków wybrzeża. Istotnie, jeszcze niedawno, jadąc z Aleksandrii w kierunku El-Alamein, widziało się po lewej stronie rudawe piaski pustyni, a po prawej najzupełniej białe plaże na brzegu Morza Śródziemnego. W krajobrazie pozbawionym nie tylko ludzi i zwierząt, ale także roślinności, ta olśniewająca biel piasku kontrastowała $z$ niewiarygodnym błękitem morza.

Warto odnotować wzmiankę o wiatrakach usytuowanych na wzniesieniu dawnego Sarapeum w okolicy samotnej kamiennej „palmy”, czyli Kolumny Pompejusza.

W Aleksandrii przebywał Słowacki zaledwie kilka dni. W tym czasie oglądał fort sułtana Qait-beya $z$ w. XV, który uważał - nie bez pewnej racji - za pozostałość 
słynnej starożytnej latarni morskiej, ,katakumby” (zapewne Kom el-Szugafa), wspomniana już Kolumnę Pompejusza, przypisywaną obecnie Dioklecjanowi, a według mnie - wzniesiona przez Antonina Karakallę $e^{23}$, oraz zabytki, których już w Aleksandrii nie ma, mianowicie tzw. wieżę Kleopatry i obeliski określane jako „igły Kleopatry".

Z Aleksandrii, po audiencji u Mohammeda Alego, obaj podróżni popłynęli łodzią do Kairu, co zajęło parę dni. Według przywoływanego już Wilkinsona:

wybierając się łodzią [z Aleksandrii] do Kairu [podróżny] dobrze zrobi wynajmując rodzaj większej kanży zwany dahabiją. Cena zależy od liczebności załogi i od pory roku. Kiedy zajmują się transportem zboża z Górnego Egiptu, cena rośnie zależnie od spadku liczby wolnych łodzi ${ }^{24}$.

Po czym autor dodaje w przypisie: „zapewne od 50 do 120 piastrów”25. Odpowiadało to sumie od 13 do 31 franków, czyli około 24 do 56 złotych polskich lub 3,3 do 8 dolarów. Przeliczenia te sa przybliżone, ponieważ, jak pisze Wilkinson, wartość piastra stale spadała ${ }^{26}$.

Słowacki odnotował w raptularzu (s. 1) daty i trasę egipskiego etapu swej wielkiej podróży:

Paździer

$12^{27} \mathrm{z}$ Syra do Alexandryi

$20 \mathrm{w}$ Alexandryi

Listop

1. w Kairze

6. z Kairu

13. w Siout

$19 \mathrm{w}$ Denderze

26. w Phila(e)

$30 \mathrm{w}$ Tebach.

grudz $10 \mathrm{w}$ Kairze

$15 \mathrm{z}$ Kairu

22 w El Arish i Kwarant

styczeń $2 \mathrm{z}$ El Arish

Słowacki przebył drogą wodna z Aleksandrii do Assuanu ponad $1150 \mathrm{~km}$, z powrotem zaś do Kairu - około $950 \mathrm{~km}$, co razem oznacza nie mniej niż $2100 \mathrm{~km}$ na Nilu, a do tego trzeba jeszcze dodać pewne odchylenia od najkrótszej trasy, a także wycieczkę z Assuanu na Philae. Łączna podróż po Nilu to zapewne w przybliżeniu $2200 \mathrm{~km}$. Podróż ta nie trwała zbyt długo, jak na warunki komunikacyjne w tamtej epoce. Widać, że nasi podróżnicy przeznaczyli na zwiedzanie Egiptu zaledwie konieczne minimum czasowe. Typowym rodzajem łodzi używanej przez turystów była wspomniana już dahabija, łódź pasażerska z dość wygodną kabina, obsługiwana przez miejscową załogę. Łódź taką Słowacki z Brzozowskim wynajęli

A. Łu k a s z w i c z, Antoninus Philosarapis. Observations on Caracalla's visit to the Sarapeum of Alexandria. Warszawa 1998. 
w Kairze 6 XI na ponad miesiąc, w celu odbycia najdłuższego etapu podróży, prowadzącego aż do pierwszej katarakty nilowej. Należy do tego dodać krótsze odcinki przebyte na wielbłądach. Najdłuższa podróż na wielbłądach to droga z Kairu do El-Arisz (starożytnej Rhinokolury) w pobliżu wschodniej granicy Egiptu. Jak wszyscy turyści, obaj podróżnicy jeździli też na osłach oraz konno.

Na trasie $z$ Kairu na południe wynajęcie łodzi było znacznie droższe niż z Aleksandrii do Kairu, ale też wynajmowano ją na czas o wiele dłuższy: według Wilkinsona najbardziej komfortowa łódź, zwana maash, kosztowała 600 do 800 piastrów na miesiąc (6-8 funtów egipskich w złocie), a kanża (qangeh) i dahabija - od 250 do 600 piastrów tarifé (2,5 do 6 funtów w złocie) ${ }^{28}$.

Wilkinson podaje kurs waluty egipskiej w stosunku do dolara i funta szterlinga $\mathrm{z}$ roku 1831: 15 piastrów $=1$ dolar, a 70 piastrów $=1$ funt ${ }^{29}$.

Dodajmy, że w XIX wieku były w Egipcie w obiegu następujące monety:

miedziaki o nominale 5, 10 i 20 para.

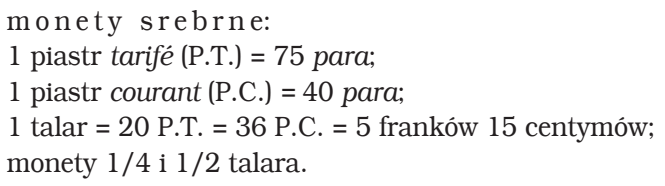

Można to łatwo przeliczyć na ówczesne złote polskie ( $1 \mathrm{złp}=30 \mathrm{gr}$ ):

1 złp = 2,16 P.T. (czyli 2 piastry i 12 para) = 162 para;

1 para $=$ ok. 0,2 gr;

1 P.T. = prawie 14 gr (14/30 złp) albo 14,04 gr według przeliczenia 1 P.T. $=0,26 \mathrm{fr}=0,468 \mathrm{złp}$ (po 30 gr);

1 funt = ok. $46 \mathrm{zł} 12 \mathrm{gr}$.

A zatem w przybliżeniu, którym mógł się w podróży posługiwać poeta:

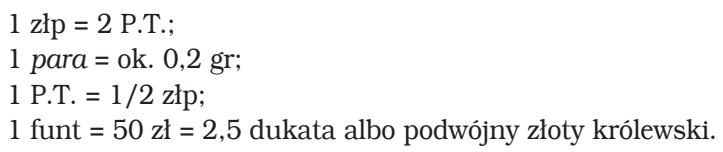

Koszty podróży do Egiptu i po Egipcie były znaczne. Ani Słowacki, ani Brzozowski nie byli dobrze zorientowani w miejscowych stosunkach oraz cenach i często przepłacali. Słowacki dał służącemu 200 piastrów, a członek załogi łodzi nilowej - według niezawodnego Wilkinsona - miesięcznie otrzymywał 25 piastrów, miesięczne zaś wynagrodzenie służącego wynosiło od 5 do 50 piastrów ${ }^{31} .100$ piastrów,

Ibidem, s. 563.

Ibidem, s. 562, przypis.

Zob. A. Graf Pr o ke s c h - O s t e n, Sohn, Nilfahrt bis zu den zweiten Katarakten. Ein Führer durch Aegypten und Nubien. Leipzig 1874, s. 13.

Wilkin s o n, op. cit., s. 563, 285. 
czyli tyle, ile Słowacki zapłacił za wielbłądy (nie wiadomo, na jakiej trasie), odpowiadało cenie wynajęcia domu w Kairze na miesiąc. Zwykle koszt wynajęcia wielbłąda na 30 dni to było 50-60 piastrów. Na pewnych trasach suma ta, z uwzględnieniem dopłat i gratyfikacji, mogła jednak wzrosnać do 100 piastrów miesięcznie, co według Wilkinsona stanowiło nader hojną zapłatę ${ }^{32}$.

\section{Kair. Piramidy}

O pobycie Słowackiego w Kairze wiemy niewiele, jeśli pominać wycieczkę do piramid w Gizie, odbytą 2 XI 1836 (data figuruje w raptularzu na s. 39, na początku rękopisu wiersza Piramidy, zaczynającego się od słów: „Wyjechałem z Kairu dziś ze słońca wschodem").

W Abusir, Sakkarze i Memfis Słowacki chyba nie był. Cennym elementem poetyckiego zapisu $z$ tego etapu podróży jest we wspomnianym utworze ukazanie malowniczej drogi z Kairu do piramid. Słowacki znakomicie przedstawia zwiedzanie wnętrza Wielkiej Piramidy. W wierszu Na szczycie piramid znajdujemy opis wspinania się na wierzchołek piramidy Cheopsa i widoku roztaczającego się stamtąd. Oględziny piramidy odbywały się, jak zwykle wówczas, w asyście miejscowych pomocników, którzy wciągali turystów do góry.

Trzeba tu koniecznie przypomnieć, że rok podróży Słowackiego do Egiptu miał poniekąd charakter przełomowy dla egiptologii. Ogłoszono właśnie Gramatyke egipska zmarłego 4 lata wcześniej Jeana-François Champolliona (1790-1832), twórcy podwalin egiptologii. We Florencji ukazało się w r. 1836, w 21 lat po śmierci Jana Potockiego, drugie wydanie jego książki Dynasties du second livre de Manéthon, która przedtem opublikowano w 1803 roku. Badania piramid w Gizie właśnie w r. 1836 weszły w decydującą fazę. Ich wnętrzem zajmował się angielski major (później pułkownik, a następnie generał) Richard William Howard Vyse (1784$1853)^{33}$. Rysunek Słowackiego $\mathrm{z}$ raptularza przedstawiajacy piramidy w Gizie zawiera niezwykle interesujące szczegóły, stanowiące świadectwo odbywających się 2 XI 1836 prac pomiarowych. Prace takie mial - według powszechnego mniemania - prowadzić wspomniany Howard Vyse. Jednak wiadomo, że 2 XI nie było go w Kairze, a prace najwyraźniej trwały. Wynika z tego, że musiał nimi kierować Giovanni Battista Caviglia (1770-1845), współpracownik Vyse’a, którego ten dopiero w roku następnym odsunął od tych działań. Rysunek wykonany przez poetę nie pozostawia wszakże wątpliwości co do intensywności samodzielnych prac Caviglii. Zmienia to nieco dotychczasowy pogląd na rolę Vyse'a w badaniu piramid. Dodajmy, że Vyse chętnie korzystał we wnętrzu piramid $z$ materiałów wybuchowych dla szybszego dotarcia do celu.

Warto tu jeszcze wspomnieć, że znacznie wcześniej piramidy w Gizie pomierzył inny Anglik, matematyk John Greaves (1602-1652). Co nadzwyczaj ciekawe, współpracownikiem Greavesa przy pomiarach piramid był w 1639 r. pewien Włoch dobrze znany z historii Polski, dokąd się przeniósł w r. 1641, Tito Livio Burattini alias Tytus

33 H. Vy se, Operations Carried on at the Pyramids of Gizeh in 1837. With an Account of a Voyage into Upper Egypt and an Appendix. T. 1-3. London 1840-1842. 
Liwiusz Boratyni (1617-1681), wszechstronny badacz, wynalazca i architekt, twórca obserwatorium astronomicznego pod Warszawa, projektant machiny latającej oraz mikroskopów i teleskopów. $Z$ jego nazwiskiem wiąże się pewien aspekt mennictwa polskiego (tzw. boratynki, czyli niepełnowartościowe miedziane szelągi z czasów Jana Kazimierza). W Egipcie przebywał Burattini w latach 1639-1641 i zaraz potem osiadł w Polsce. Był autorem traktatu Misura universale wydanego w Wilnie w r. 1675, w którym proponował wprowadzenie ujednoliconej powszechnej miary długości, nazwanej metrem. Greaves wykorzystał rysunki Burattiniego z Egiptu w swoim dziele Pyramidographia (1646). Także słynny polihistor i egiptolog, jezuita Athanasius Kircher (1602-1680) korzystał z materiałów Burattiniego. Burattini był egiptologiem-amatorem, napisał w Egipcie traktat o wylewach Nilu, noszacy tytuł Niloscopio, później zmieniony na Nuova dimostrazione dell'inondazione del Nilo ${ }^{34}$.

W czasach Słowackiego, i długo po nich, na piramidy wspinał się kto żyw: zwykli turyści, awanturnicy i uczeni. Opisów i ilustracji tego procederu, dziś zakazanego, zachowało się co niemiara. Warto może przywołać tutaj przykład odległy o zaledwie 6 lat od pobytu Słowackiego nad Nilem, a mianowicie - wielkiego egiptologa niemieckiego Karla Richarda Lepsiusa (1810-1884), który 15 X 1842 wraz z członkami pruskiej ekspedycji wdrapał się na piramidę Cheopsa, zatknął tam biała flagę $z$ czarnym orłem i pozostawił pompatyczny napis hieroglificzny ${ }^{35} \mathrm{ku}$ czci swego monarchy i mecenasa ekspedycji, Fryderyka Wilhelma IV, którego urodziny przypadały w tym dniu. Powstała wtedy malarska panorama, autorstwa Josepha Bonomiego i Johanna Jakoba Freya, przedstawiająca widok ze szczytu piramidy ${ }^{36}$. Współczesny egiptolog Horst Beinlich, korzystający w swoim dziele Mit Richard Lepsius auf die Cheops-Pyramide z różnych opisów i ilustracji dotyczących znanych postaci, które weszły na piramidę, nie wspomina oczywiście o Słowackim - o jego istnieniu nie ma zapewne w ogóle pojęcia.

Na szczycie piramidy Słowacki przeczytał polski napis przypominający datę wybuchu powstania. Cytuje go Jan Stanisław Bystroń, twierdząc, że autorem był generał Henryk Dembiński, który przebywał w Egipcie w 1833 roku. Napis brzmiał: „Przekażcie wiekom pamiętny dzień 29 listopada 1830 roku” ${ }^{37}$. Inskrypcji tej już nie ma.

Wcześniej hrabia Jan Potocki (1761-1815), o którym pamiętamy zwykle jako o autorze ekscentrycznego Rękopisu znalezionego $w$ Saragossie, zapominając o jego pismach naukowych dotyczacych Egiptu ${ }^{38}$, w graffito wyrytym na piramidzie Cheopsa we wrześniu 1784 posłużył się cytatem z poematu Ogrody Jacques’a De-

Zob. Who Was Who in Egyptology. Ed. M. L. Bi e rb rie r. Wyd. 4, popr. London 2012, s.v. Burattini Tito Livio. Zob. też Polski słownik biograficzny. T. 3. Kraków 1937, s. 133-136.

Napis reprodukowany w publikacjach, ostatnio w pracy H. Beinlich a Mit Richard Lepsius auf die Cheops-Pyramide (Dettelbach 2010), gdzie jest także ilustracja przedstawiająca grono Prusaków na szczycie tej piramidy.

Zob. Karl Richard Lepsius. Der Begründer der deutschen Ägyptologie. Ed. V. M. Le p p e r, I. Hafe mann. Berlin 2012. - Beinlich, op. cit.

Zob. Bystroń, op. cit., s. 161. Zob. też Przybylski, op. cit., s. 61, 112, przypis 16.

J. Pot o cki: Dynasties du second livre de Manéthon. Florence 1803 (wyd. 2: 1836); Chronologie des deux premiers livres de Manéthon. St. Pétersbourg 1805; Examen critique du fragment égyptien connu sous le nom d'Ancienne chronique. St. Pétersbourg 1808; Principes de chronologie pour les 
lille’a (1738-1813): „Leur masse indestructible a fatigué le temps” (w przekładzie Juliana Ursyna Niemcewicza brzmi to nieco mniej zgrabnie: „Gmachy te niewzruszone sam czas zmordowały"39). Cytat - wybrany znakomicie - stanowi niejako odpowiednik znanego powiedzenia, że czas boi się piramid. Potem nie wiedziano już, kto to napisał. Francuski egiptolog Georges Goyon, publikując graffiti znajdujące się na piramidzie Cheopsa, nie zidentyfikował autora tej inskrypcji ${ }^{40}$.

Zwyczaj wydrapywania własnych imion, dat itp. na zabytkach egipskich sięga odległej starożytności. Również Francuzi Bonapartego hołdowali mu gremialnie. W czasach postnapoleońskich w środowisku byłych kombatantów śpiewano nostalgiczną pieśń napisaną przez wierszokletę nazwiskiem Paul-Émile Debraux, ze słowami:

$$
\begin{aligned}
& \text { Te souviens-tu que sur les Pyramides } \\
& \text { chacun de nous osa graver son nom? } \\
& \text { [Pamiętasz jak na piramidach } \\
& \text { każdy z nas śmiało się podpisał?] }
\end{aligned}
$$

I dalej, z dumą byłych zdobywców:

$$
\begin{aligned}
& \text { On vit flotter, après l'avoir vaincu } \\
& \text { Notre étendard sur le berceau du monde }{ }^{41} \text {. } \\
& \text { [A po zwycięstwie sztandar nasz } \\
& \text { powiewał nad kolebką świata.] }
\end{aligned}
$$

Stworzone przez Słowackiego poetyckie obrazy piramid w Gizie, jak w wierszu $\mathrm{Na}$ szczycie piramid, należą do najlepszych opisów literackich tych grobowców faraonów w całej literaturze światowej.

\author{
Czas i życie. - Spojrzałem na błękit rozciągły, \\ Świat przybrał kształty Bogiem widziane - był kragły. \\ $Z$ dala Kair... Nil... łąki - daktylowe laski... \\ Bliżej pustynia... złotem oświecone piaski... \\ Bliżej trzy drzewa... figa... pod nią cienia chłodnik, \\ A w nim stał mój osiołek i Arab przewodnik. \\ Patrząc na nich myślałem... o mrówce ze srebra... \\ Bliżej dolina piasku - cała w równe żebra \\ Wichrem zmarszczona... i Sfinks, i grobowce białe - \\ Ziemia widoma... wszystko dojrzane, lecz małe... \\ Inny widok na prawo... inna była scena: \\ Naprzeciwko Cheopsa - stał pomnik Cefrena, \\ Tak że orzeł po równej krainie błękitu \\ Mógł płynać od jednego - do drugiego szczytu. \\ Dwie piramidy wąwóz tworzyły głęboki, \\ A zachodniego słońca czerwone potoki \\ Jakby falami ognia płynęły tamtędy, \\ Lejąc się przez grobowców utworzonych rzędy. [s. 158-159, w. 11-28]
}

temps antérieurs aux olympiades. St. Pétersbourg 1810; Principes de chronologie pour les douze siècles qui ont précédé les olympiades. T. 1-6. Krzemieniec 1813-1815. 
Pisownia „Cefrena” zamiast „Chefrena” należy do ówczesnej maniery (podobnie u Anglików: np. u Anne Elwood w r. 1830: „Cephrenes” ${ }^{2}$ ).

Słońce zachodzi, co znaczy, że wycieczka do piramid zajęła poecie cały dzień, bo zaczęła się rankiem.

\author{
I większy był jeszcze \\ Widok w myślach - na wieki lecące jak deszcze \\ Po granitowych ścianach; na pożarów łuny, \\ Na ogromnych wypadków bijące pioruny... \\ Kiedym to wszystko wstawil - i w grobie pochował, \\ Zdało mi się, że Mojżesz krwią Nil zafarbował \\ I że płynał czerwony... wypadków posoka; \\ A tak myślac, po głazach obłąkane oko \\ Padło na jakiś napis - strumień myśli opadł... \\ Ktoś dwudziesty dziewiąty przypomniał Listopad, \\ Polskim językiem groby Egipcjanów znacząc... \\ Czytałem smutny... człowiek może pisał płacząc. [s. 160, w. 31-42]
}

Mała piramidka przypisywana przez Słowackiego córce Cheopsa wzrusza poetę do łez. Inaczej podchodził do tego Potocki - żartem naliczył on 167383 i pół kamienia, które zostały dostarczone według Herodota przez kochanków egipskiej królewny, po jednym za każdy... fawor. Potocki zauważył przy okazji, także żartem, że to imponująca liczba jak na młodą dziewczynę ${ }^{43}$. Nie wyjaśnił jednak, za co ktoś przyniósł rzekome pół kamienia. Nie wiadomo na pewno, którą z piramid uznawał Potocki za piramidę córki Cheopsa. Być może, pomylił historię o tej królewnie, wzięta z Herodota, z opowieścią o kurtyzanie Rodopis i piramidzie Mykerinosa.

Słowackiego fascynuje wielość bogów egipskich i mumifikacja ciał królów. Podziwia też monumentalną architekturę. Wobec ogromu piramid zachowuje jednak dystans. Bardziej mu imponują wyimaginowane struktury stworzone przez ludzką wyobraźnię. Jako wielbiciel Szekspira twierdzi, że Makbet to „granitowa piramida zbrodni”, a Król Lear jest „piramidą nieszczęścia”, demoniczną zazdrość Otella porównuje zaś do obelisków, które bodą niebo (List do Aleksandra H., s. 168, w. 104, 106, 108). Warto zauważyć, że Słowacki wspomina w Liście do Aleksandra H. rzekomą role piramid jako swoistych obserwatoriów astronomicznych, używanych jakoby przez egipskich kapłanów, czemu miały służyć wewnętrzne korytarze $\mathrm{z}$ wylotami skierowanymi na określone punkty nieba (s. 168, w. 109-110), który to pogląd już dawno odrzucono. I znowu pojawia się zestawienie z Szekspirem - w jego dramatycznej perspektywie Słowacki dopatruje się alegorycznego widoku niebios oraz Boga. Poeta skłania się ku przekonaniu, że piramidy miały szczególne właściwości sprzyjające zachowaniu ciał (s. 166, w. 83-84).

Wiersz [Rozmowa z piramidami] też zawiera obiegowe pojęcia o egipskiej religii, wierze $\mathrm{w}$ życie pozagrobowe i sztuce balsamowania. W utworze tym pojawia się motyw zabalsamowania w piramidach miecza - narzędzia zemsty za klęski i upo-

A. K. Curte is E1w o od, Narrative of a Journey Overland from England, by the Continent of Europe, Egypt and the Red Sea [...] in the years 1825, 26, 27, and 28. London 1830, s. 158. Podaję za: Beinlich, op. cit., s. 75.

43 J. Poto cki, Podróże. Oprac. L. Ku kulsk i. Warszawa 1959, s. 76. Zob. też tego autora: Oeuvres. Éd. F. Ross et, D. Triaire. T. 1. Louvain 2004, s. 54. 
korzenia narodu. Także i męczennicy sprawy narodowej moga jakoby uzyskać przetrwanie do przyszłej chwili odrodzenia. Słowacki pyta retorycznie:

\author{
Piramidy, czy wy macie \\ Takie trumny i łzawice, \\ By łzy nasze i tęsknice \\ Po ojczystych pól utracie \\ Zlać tam razem - i ostatek \\ Czary dolać łzami matek? [s. 182, w. 17-22]
}

Ten utwór, w którym również grobowce egipskich faraonów przemawiają do poety, znajduje pewną odległa analogię w wierszu Percy'ego Bysshe Shelleya Ozymandias, gdzie napis na piedestale powalonego i połamanego kolosa Ramzesa II głosi: „Ja jestem Ozymandias, król królów”44. Dodajmy, że Shelley nie był w Egipcie, a inspirację zaczerpnął $\mathrm{z}$ wystawionego w Londynie w $1817 \mathrm{r}$. fragmentu posagu. Natomiast w poemacie Théophile'a Gautiera Nostalgies d'obélisques z r. 1851 obeliski luksorskie rozmawiaja ze sobą.

Nie ulega wątpliwości, że wspomniana przez Słowackiego „utrata ojczystych pól", to nie tylko klęska powstania listopadowego i okrojonego Królestwa. Słyszymy tu lament polskiego Jeremiasza nad upadkiem dawnej rozległej Rzeczypospolitej.

\title{
Podróż na południe. Dzieje Egiptu
}

W Kairze 6 XI 1836 Słowacki z Brzozowskim wynajęli na miesiąc dahabiję z 8-osobową załogą miejscową, złożoną z ludzi nie budzacych - jak się zdaje - większego zainteresowania poety. Nie odnotował on nawet ich imion. Na owej łodzi powiewała flaga francuska, czego dowodzi (niezbyt zresztą udana) akwarela namalowana przez Słowackiego (z podpisem „Luxor - łódka nasza”), przedstawiająca tę łódź przy wschodnim brzegu Nilu w Luksorze, w pobliżu świątyni Amona, opublikowana niedawno w Album rysunkowym z podróży na Wschód ${ }^{45}$. Jakaś flaga (pavillon) musiała być, taki panował zwyczaj, choćby ze względu na miejscowe kontrole, na opiekę konsula oraz na paszport i firmany ${ }^{46}$ od Mohammeda Alego.

Słowacki nie zna miejscowego języka, jednak posiłkuje się mizernym dykcjonarzykiem własnej roboty, zachowanym w raptularzu. Napisze potem do matki z Libanu w liście datowanym 14 VI 1837:

dziewczęta wiejskie przychodziły czerpać wodę, i rozmawiałem z nimi po arabsku, a trzeba wiedzieć, że cały mój arabszczyzny zabytek składa się z 200 wokabuł bez spójników i przypadkowych zakończeńn ${ }^{47}$.

Egipt inspiruje do tworzenia poezji. Jest w nim jakaś magia skłaniająca do

P. B. Sh elley, Ozymandias. W zb.: Ancient Egypt in Poetry. An Anthology of Nineteenth-Century Verse. Ed. D. B. Ryan. Cairo - New York 2016, s. 23-24. Przekład A. A s nyka w zb.: Poeci języka angielskiego. Wybór, oprac. H. Krzeczkowski, J. S. Sito, J. Żuławski. T. 2. Warszawa 1971, s. 339.

45 J. Sło w a c ki, Album rysunkowe z podróży na Wschód. Wstęp, komentarz E. G rzę d a. Wrocław 2009, s. 131.

46 Firmany - oficjalne dokumenty wystawiane przez władców w dawnych państwach muzułmańskich.

47 Słow a cki, Listy do matki, s. 294. 
refleksji. Pisanie wierszy na Nilu miało też pewien aspekt prozaiczny - Słowacki w Egipcie próżnował, zwłaszcza na nilowej dahabii. Wszystko załatwiała służba, a europejski pasażer tylko oglądał krajobrazy, medytował, jadł, pił, spał, ewentualnie notował wrażenia. Poeta wspomni o tym w liście do matki wysłanym $z$ Bejrutu 17 II 1837: „Mnie miło było polować na piaskach, rysować szkice pomników, chatek, dumać i myśleć o tym, że jestem w Egipcie" ${ }^{48}$. Nie budzi szczególnego zachwytu fakt, że w Górnym Egipcie Słowacki zajmował się polowaniem, co może dałoby się jakoś wytłumaczyć koniecznością zdobycia świeżego mięsa. Podejrzewam jednak, że polował dla przyjemności. Było to powszechne wśród podróżników przemierzających Egipt. Poeta dostrzega co nieco z egipskiej przyrody: palmy oraz inne drzewa, osły i wielbłądy, nawet perłowej barwy mrówki, także ptaki - głównie gołębie, a czasem bociany, kojarzące się z Polską (Hymn 〈„Smutno mi Boże...”). Psów i kotów nie widzi. Zwierzęta dzikie to obiekty polowania albo ciekawostka, jak krokodyle. Słowacki napisał do matki w cytowanym tu już liście z Bejrutu: „Nareszcie przy Siut pierwszy krokodyl leżący na piasku, dla którego porwaliśmy się od stołu, aby mu się z bliska przypatrzeć" 49 . W owych czasach krokodyle można było spotkać dopiero w Górnym Egipcie. Zwierzęta te, uchodzące za agresywne, według Wilkinsona są dość płochliwe i tylko wyjątkowo nieostrożni ludzie padają ich ofiarą ${ }^{50}$.

Wschód budzi u poety pozytywne skojarzenia, tylko nie ma on dość czasu, by weń wniknąć, i przemyka się po powierzchni dostrzeganych zjawisk. Słowacki był człowiekiem nieźle wykształconym i niewątpliwie przygotował się do podróży, jednak trudno byłoby odtworzyć zestaw jego lektur, gdyż wybór tego rodzaju publikacji był już wtedy dość znaczny.

List do Aleksandra H. zawiera zwięzłą syntezę dziejów Egiptu. Jest to może najkrótsza historia Egiptu, jaką kiedykolwiek napisano, a zarazem pewnego rodzaju dialog z Hołyńskim, który - jak czytamy w wierszu - podróżuje ze Strabonem i Manethonem, gdy tymczasem poeta podziwia piękno kraju nad Nilem. Mimo tej deklaracji Słowacki stara się wykazać, że on też zna starożytne dzieje państwa faraonów. Jego wiedza jest dość powierzchowna, ale odzwierciedla stan ówczesnej podręcznikowej wulgaty historycznej. Zgodnie $\mathrm{z}$ rozpowszechnionym do dziś przekonaniem poeta uważa cywilizację egipska za wyjątkowo trwała i niezmienną. Ta niezmienność go drażni. Zna on rozmaite epizody z dziejów Egiptu w wersji przekazanej przez autorów antycznych. Drwi z opowieści o Menesie (którego nazywa Manesem), rzekomo „zjedzonym” przez hipopotama. Rewolucyjny zapał skłania go do stwierdzenia, że takie „królobójcze zwierzę” przydałoby się w jego czasach.

Według Słowackiego Hyksosi ${ }^{51}$, którzy podbili Egipt, byli budowniczymi pierwszej piramidy. Nie jest to jego własny pomysł. Podobne mylne interpretacje tekstu Herodota $^{52}$ krążyły w ówczesnej literaturze. Poeta nie czytał zapewne dziełka Potockiego o Manethonie z r. 1803, zawierającego chronologię zdumiewająco bliską

Ibidem, s. 285 .

Ibidem, s. 284.

Wilkin s o n, op. cit., s. 409.

Hyksosi to nie nazwa określonego ludu, ale termin egipski oznaczający „władców obcych krajów”. Były to trudne do zidentyfikowania plemiona semickie.

H e r o d ot, Dzieje, II 128. 
temu, co wie dzisiejsza nauka ${ }^{53}$. Uważał Filistynów (znanych z Biblii) za potomków Hyksosów wygnanych z Egiptu. Także i ten pogląd pojawia się w XIX-wiecznej literaturze egiptologicznej. Słowacki nadmienia w wierszu, że budowle Filistynów nie dorównywały jakością piramidom (wzniesionym rzekomo przez ich przodków), gdyż żydowski mocarz Samson bez trudu zburzył ich świątynię, grzebiąc pod jej gruzami tłum Filistynów i samego siebie (Sdz 16, 25-30).

Poeta w Liście do Aleksandra H. zwięźle opowiada o cudach Mojżesza w Egipcie. Trudno dociec, czy jego pogląd na te wydarzenia, znane z Biblii, jest zgodny z kanoniczną interpretacją. Wydaje się, że z pewnym współczuciem myśli on o nieszczęściach faraona i ludu egipskiego. Tak czy inaczej, stwierdza, że były to zdarzenia wyjątkowe w dziejach starożytnych (s. 166, w. 82).

Mumifikacja należała - zdaniem Słowackiego - do wielkich osiągnięć ludzkości. Pisze on też, że w starożytnym Egipcie sądzono króla po śmierci, by przyznać mu prawo do pogrzebu lub tego prawa odmówić. Pogląd ów pochodzi z dzieła Diodora Sycylijskiego ${ }^{54}$. Nasz wieszcz dodaje, że potwierdzają to puste sarkofagi w piramidach i innych grobowcach, aczkolwiek dorzuca rozsądnie, iż uczeni mogą na ten temat mieć inne zdanie. O rzekomym sądzie nad zmarłym królem pisał potem także Bolesław Prus w Faraonie, aczkolwiek objaśniał to jako czysta formalność, służącą w gruncie rzeczy pochwale nieboszczyka. Słowacki wspomina związek egipskiego miasta Sais z Atenami. Grecka architekturę uznaje za dalszy rozwój pierwowzorów egipskich. Zaskakujące porównanie świątyni Amona w Luksorze, uważanej przez Słowackiego (i przez wielu innych autorów XIX-wiecznych) za pałac, do jakoby współczesnego tej świątyni „domu Ewandra” (s. 171, w. 141) wynika oczywiście z doświadczeń Słowackiego wyniesionych z pobytu w Rzymie, gdzie, być może, pokazywano mu na Palatynie jakieś ruiny z okresu cesarstwa jako rzekomy dom mitycznego Euandra. Świątynia luksorska jest skądinąd znacznie wcześniejsza od legendarnych początków Rzymu. Dalej następuje w wierszu wyliczenie kolejnych etapów egipskiej historii: najazd perski, zagłada armii perskiej w czasie burzy piaskowej na egipskiej pustyni, podboje Aleksandra Wielkiego, ogłoszonego synem Zeusa-Ammona, jego rychła śmierć, odrodzenie Egiptu pod berłem Ptolemeuszów, których wieszcz chwali za popieranie nauki, wreszcie podbój przez Rzymian. Tu pojawia się wymowny obraz mieszkańca Tentyry (Dendery) walczacego $\mathrm{z}$ krokodylem $\mathrm{w}$ amfiteatrze na oczach rzymskiej gawiedzi, nowych władców świata. Tentyra nad Nilem, której mieszkańcy rzeczywiście słynęli jako pogromcy krokodyli, jest w wierszu miejscem świątyni bogini Hathor, obfitującym w palmy daktylowe. Poeta, być może, czytał znana satyrę Juwenalisa, w której mowa o Tentyrze ${ }^{55} \mathrm{w}$ związku $\mathrm{z}$ palmami, a w czasie swego własnego pobytu 19 XI w Denderze, gdzie zachwyciła go wspaniała świątynia, zaobserwował z pewnościa liczne w tej okolicy gaje palmowe. Słowacki przypomina w wierszu, że po upadku państwa faraonów liczne obeliski egipskie zostały zabrane w dalekie strony. Kiedy nad Nil dotarło chrześcijaństwo, Tebaida stała się siedliskiem pustelników. Po

53 Potocki, Dynasties du second livre de Manethon.

54 Diodor Sycylijs ki, Biblioteka historyczna, I 72.5; 92.1-4.

55 J u w en a lis, Satyra XV. Przeł. J. S ę k ow s ki. W zb.: Trzej satyrycy rzymscy. Horacy - PersjuszJuwenalis. Wstęp i komentarz w oprac. L. Winni czu k. Warszawa 1958. 
wzmiance o chrześcijańskich eremitach mieszkających w grobach tebańskich zjawia się w tym przeglądzie dziejów „Omar straszny głowom, gmachom i księgarniom” (s. 174, w. 188). Tak ulega Słowacki legendzie, która z Amra ibn al-Asa, umiarkowanego zdobywcy i rozsądnego administratora, uczyniła barbarzyńskiego niszczyciela biblioteki aleksandryjskiej. Paradoksalnie, ów rzekomy sprawca zagłady greckich ksiag podpisał się na ścianie jednego z królewskich grobowców w Dolinie Królów w Tebaidzie... po grecku ${ }^{56}$.

Poeta zapowiada spotkanie z Hołyńskim właśnie w „pełnej grobowców Tebaidzie”, ale nie przy świecy wstawionej w czaszkę pustelnika, tylko w atmosferze wczuwania się w starożytność i przeżywania jej aż do pełnej identyfikacji.

Lecz dosyć już; bo sądzę, nowy księżyc przyjdzie

Oświecać nas w grobowców pełnej Tebaidzie...

Tam niech inni o życia rozmawiają fraszce,

Paląc świecę w pożółkłej pustelnika czaszce:

My chcąc pojąć, jak niegdyś żyli ludzie sławni,

Staniemy się myślami i rozmową dawni,

Aż się tak obłąkamy w wypadkowym lesie,

Jak w palmach biały gołąb, co ten list poniesie. [s. 174, w. 191-198]

\section{Hieroglify. Poglądy Słowackiego}

Hieroglify egipskie przypominaja Słowackiemu - jak wynika z Listu do Aleksandra H. - legendarne skarby, których strzega gryfy. To motyw antyczny, znany $z$ Herodota ${ }^{57}$.

Jako skarby zaklęte, strzeżone przez gryfy,

Stoją dotąd nieznane światu hieroglify. [s. 168, w. 113-114]

To, że hieroglify są „nieznane”, stanowi jednak prawdę tylko częściową, o czym zaraz Słowacki powie.

\section{[...] Z długimi przestanki}

Idąc, prawie połowę drogi uszli Franki. [s. 168, w. 117-118]

Dzieło Champolliona poświęcone gramatyce egipskiej nie przyniosło jeszcze pełnej wiedzy o języku i piśmie, ale system został rozpoznany. Dalsze kroki poczynili wicehrabia Emmanuel de Rougé (1811-1872) i Karl Richard Lepsius, który był autorem nazwy „egiptologia”. Wieszcz pisze jednak niezgodnie z ustaleniami Champolliona:

Już wiadomo, że w tamtą stronę czytać znaki,

W którą lwy ryte patrzą, w którą lecą ptaki. [s. 168, w. 119-120]

W rzeczywistości znaki figuralne patrzą w stronę miejsca, od którego powinno się podejmować lekturę. Może Słowacki chciał jednak powiedzieć: od tamtej strony należy zaczynać czytanie, w którą patrzą znaki, tylko wyraził to niezręcznie. Wiedział on o alfabetycznym aspekcie pisma egipskiego. Lecz pogląd, że było ono w całości 2013, s. 134.

57 Her od ot, Dzieje, III 116; IV 13; 16. 
alfabetem, w dodatku akrostychicznym, a więc złożonym z początkowych głosek wyrazów oznaczających przedstawione przedmioty, jest błędny. Słowacki dodaje, że w pracy egipskiego skryby było coś poetycznego.

Autor Listu do Aleksandra H. protestuje przeciwko grabieży egipskich zabytków:

Dziś gorsi i podobni do Mojżesza plagi,

Cudzoziemcy wynoszą z grobów sarkofagi.

Anglik dumny ${ }^{58} \mathrm{w}$ sterlingi ${ }^{59}$ zmienione na piastry,

Rzuca trupy, trumiane ${ }^{60}$ bierze alabastry,

I w Londynie zachwyca zgraję zadziwiona,

Wstawiwszy świecznik w próżne alabastru łono. [s. 172, w. 165-170]

Wzmianka o świecy dotyczy efektów pokazywanych w czasie wystawy w Londynie w latach 1820-1821. Był to plon działalności Giovanniego Battisty Belzoniego (1778-1823) i Henry’ego Salta (1780-1827), głośnej w ówczesnej Europie, polegajacej na prowadzeniu prac odkrywczych i wykopaliskowych w Egipcie oraz wywożeniu stamtąd zabytków. Działalność ta wywoływała ogólny zachwyt, ale Słowacki go nie podzielał. Ukazuje on w wierszu stojacy w Rzymie obelisk (ten akurat zabrany z Egiptu jeszcze w starożytności), brutalnie wydarty z egipskich ruin, osamotniony w obcym mu świecie, nie będacy nawet w stanie zapewnić cienia głowie żebraka; nie cieszy go szumiąca u stóp rzymska fontanna, marzy bowiem o dalekiej ojczyźnie (s. 172, w. 159-164). W jednym $z$ listów poeta ubolewa nad osamotnieniem luksorskiego obelisku, którego bliźniaka wywieziono do Paryża ${ }^{61}$. Champollion, przebywający w Egipcie w latach 1828-1829, także sprzeciwiał się grabieży egipskich zabytków, jednak (w liście z 25 III 1829), odpowiadając na zapotrzebowanie władz zainteresowanych przywiezieniem obelisku, sugerował ostrożnie możliwość zabrania jednego $\mathrm{z}$ dwóch takich monumentów sprzed luksorskiej światyni ${ }^{62}$. Obelisk staną na place de la Concorde 25 X 1836, akurat w czasie pobytu Słowackiego w Aleksandrii.

Wydaje się, że poeta nie doceniał zainteresowania, jakie u poszukiwaczy zabytków budziły egipskie mumie. Wcale nie wszystkie wyrzucano, by zabrać tylko sarkofagi. Odwijanie mumii i sekcje starożytnych zwłok należały do ulubionych rozrywek ekscytujących szerszą publiczność w Europie, zwłaszcza w Anglii. Los ten spotkał dziesiątki tysięcy mumii ${ }^{63}$. Zachowały się bilety, które sprzedawano na te spektakle.

Tak właśnie w raptularzu, co wydaje się omyłką poety, bo jedynie właściwe byłoby słowo „dufny”, jak przyjął J. Krzyżanowski w swoim opracowaniu utworu - zob. Słowacki, Dzieła, t. 1, s. 94.

W rękopisie z raptularza: „szterlingi”.

W raptularzu: „kości” (a nie „trupy”) oraz „trumniane”.

J. Słow a cki, Korespondencja. Oprac. E. Sawry m ow ic z. T. 1. Wrocław 1962, s. 376-377.

Zob. J.-F. Ch a m pollio n, Lettres et journaux écrits pendant le voyage d'Égypte. Recueillis et annotés par H. Hartleben. Guernesey 1986, s. 249: „si le gouvernement veut un obélisque à Paris, il est de l'honneur national d'avoir un de ceux de Louqsor (celui de droite en entrant) [...] 300.000 francs feraient l'affaire [jeśli rząd chce obelisku w Paryżu, to honor narodowy wymaga, żeby to był jeden $z$ obelisków luksorskich (ten, który stoi na prawo od wejścia) [...] 300000 franków załatwiłoby sprawęl".

Zob. A. Łukaszewicz, Mumie egipskie $w$ rękach nowożytnych profanów. „Studia i Materiały Archeologiczne" t. 15 (2016), s. 91-98. 
Podobnie jak Francuzi w czasach ekspedycji Bonapartego, Słowacki zachwycał się prawie nietknięta świątynią w Denderze. Uważał ją za zabytek egipski ustępujaccy jedynie wielkim piramidom w Gizie. Ogrom i majestat Karnaku i Luksoru nasuwał mu myśli o wiecznotrwałości dzieł egipskiej cywilizacji. Zwiedził też świątynie Teb Zachodnich: Ramesseum oraz Medinet Habu. Podziwiał i narysował o zachodzie słońca tzw. kolosy Memnona. Cytuje słowo z jednej z łacińskich inskrypcji na posagu. Dowodzi to albo dobrego wzroku, albo zręcznego wspinania się na północny posag Amenhotepa III, zwany kolosem Memnona, gdyż ta akurat inskrypcja znajduje się dość wysoko. Był też Słowacki w Dolinie Królów, zwiedzał grobowce faraonów, a może nawet nocował $\mathrm{w}$ jednym $\mathrm{z}$ nich? O ile wiadomo, nie pozostawił podpisu na egipskich zabytkach, inaczej niż wielu współczesnych mu podróżników. Nic też nie wskazuje na to, by zabierał z Egiptu jakieś „pamiątki”. Z Teb poeta udał się Nilem przez Armant (Hermonthis) i Edfu do Assuanu. Dotarł do wyspy Philae ${ }^{64}$, gdzie narysował starożytne budowle. W czasie podróży szkicował nie tylko monumentalne świątynie i grobowce. Interesowały go także wioski, lepianki $z$ nilowego mułu, meczety i palmowe zagajniki, o czym świadcza jego rysunki. List do Aleksandra $H$. dowodzi, że Słowacki znał przyczyny wylewów Nilu: wiedział o deszczach w Abisynii, o moczarach i jeziorach w górnym biegu Białego Nilu (s. 163-164, w. 19-36). W wierszu tym poeta wprowadza do swojego erudycyjnego wykładu ekskurs o źródłach Nilu, wtedy jeszcze nie odkrytych. Nimfa u źródeł Nilu, może jest - powiada - „taka, jak wiezione Abissy na przedaż” (s. 163, w. 29); to reminiscencja „łodzi kupczącej ludzkim ciałem" (s. 162, w. 15), tzn. wiozącej na sprzedaż abisyńskie niewolnice. "Abissa" to odwieczne nieporozumienie - mylne skojarzenie starożytnej nazwy kraju Habesz, czyli Abisynii (Etiopii), z greckim wyrazem „abyssos” 'otchłań, przepaść'. Za chwile jednak Słowacki wycofa się $z$ własnej wizji i zamieni rzekomą nimfę w „błotne jeziora” -

\section{Z których każde [...]}

[...] deszczami tropików nabrzmiewa,

Aż zwiększone ulewą i skalnymi ścieki

Rzuci wszystko Nilowi gardłem białej rzeki. [s. 163-164, w. 33-36]

Trochę to nieścisłe, bo przybór pod wpływem deszczów bierze się z Nilu Błękitnego. Deszcze padaja (ale nie „przez rok cały”, jak w w. 34) w górach Etiopii, a nie w górnym biegu Nilu Białego, gdzie są owe „błotne jeziora”.

Ciekawe, czy to nie passus o tej nilowej nimfie zainspirował Boya-Żeleńskiego do ironicznego wyrażenia:

A te w czułym atramencie

Urodzone nimfy wodne

Pana Słowackiego Jula,

O którego... mankamencie

Wie dzisiaj każda smarkula,

I który mu wypomina

Nawet Świderska Alina! ${ }^{65}$

64 W Polsce często nazwę tę zapisuje się: File, co budzi nieuzasadnione skojarzenia z greckim rzeczownikiem , file" "przyjaciółka'. Tymczasem nazwa jest egipska.

65 T. Żeleński (B oy), Replika kobiety polskiej na odpowiedź młodzieńca polskiego. W: Słówka. Wydanie nowe. Przedm., komentarz ... Wyd. 8. Kraków 1973, s. 57. 
Zaraz potem następuje w Liście do Aleksandra $H$. syntetyczny opis egipskiego krajobrazu, a po nim komplementy zwrócone do młodego adresata, któremu Słowacki przypisuje znajomość źródeł i dociekliwość historyczną, przeciwstawiając ją własnej wrażliwości na „piękność Nilu”. Kryje się w tym dyskretne poczucie wyższości romantyka nad erudytą.

Dalej czytamy:

Ja chcę prędkich rozkwitnień, owoców i zgonów.

Gniewa mię nieruchomość długa faraonów, [s. 165, w. 57-58]

Poeta znalazł w Egipcie inspirację dla swojej późniejszej mistyki, w której przyznał Bogu, „wiecznemu rewolucjoniście”, rolę sprawcy przemian świata. Ale Słowacki pojmował dawny Egipt jako nieużyteczny, nieruchomy kryształ, przeciwieństwo ruchu i ewolucji66. Taka jego „statyczną” wizję głosiła też wczesna egiptologia. Do dziś popularna interpretacja czyni z państwa faraonów „Staat aus dem Stein”, Egipt nieruchomy i niezmienny przez tysiąclecia. Wiemy jednak, że starożytny Egipt zmieniał się i rozwijał szybciej, niż kiedyś myślano, zachowując wszakże przy tym zdumiewająco wiele $z$ dziedzictwa poprzednich epok swej długiej historii. Mistyczna interpretacja Egiptu była rozpowszechniona w XVIII i XIX wieku. Należała do ideologicznego repertuaru wolnomularstwa, zwłaszcza przed odczytaniem hieroglifów, kiedy można było pozwalać sobie na fantazjowanie na temat rzekomej „tajemnej wiedzy” Egipcjan. Pojawienie się naukowej egiptologii przyczyniło się do ogromnej popularyzacji dziedzictwa tego kraju zarówno w kręgach intelektualnych, jak i wśród szerszej publiczności. W wieku XIX trwało przekonanie, że działały tam tajne struktury kapłańskie, dysponujące sekretną wiedzą. Literaci nadal tworzyli fantastyczny Egipt pełen tajemnic, magii i rytuałów związanych z życiem pozagrobowym, a zwłaszcza $z$ mumifikacją.

Słowacki w czasie pobytu nad Nilem liczył sobie zaledwie 27 lat. Egipt nie był głównym celem jego podróży. Spędził tam niewiele ponad dwa miesiące.

Egipt otwierał się właśnie dla nowego pokolenia entuzjastów. Słowacki, syn znawcy literatury antycznej, napisał do matki, że Grecja i Włochy nie wytrzymuja porównania z Egiptem, który jest najwspanialszym krajem świata starożytnego. Szkoda, że poeta nie zostawił dokładnego opisu podróży. Byłby polską Amelią Edwards ante litteram ${ }^{67}$, a tak nie stał się nawet prekursorem Władysława Wężyka (1816-1848). Ten ostatni w kilka lat po Słowackim naszkicował błyskotliwy, i zbyt mało doceniany, obraz tego kraju ${ }^{68}$. Jednak wizerunek Egiptu pozostawiony przez Słowackiego odznacza się lapidarnością i wielką siłą ekspresji, a poza tym jest wyjątkowym w polskiej poezji przejawem zainteresowania państwem faraonów.

Zob. J. Słow a cki, Genezis z Ducha. W: Dzieła wszystkie. T. 14. Oprac. W. Flo ry a n, J. Klein er. Wrocław 1954, s. 48, w. 78-81: „bo to są Egipcjanie pierwszej natury, którzy na lat tysiące ciała sobie budowali, ruchem pogardzili, w trwaniu i w spoczynku rozmiłowali się jedynie”.

67 Amelia Edward s (1831-1892), założycielka Egypt Exploration Fund (później Egypt Exploration Society), autorka opisu Egiptu z 1874 roku. 
Abstract

ADAM ŁUKASZEWICZ University of Warsaw

\section{THE YEAR 1836: JULIUSZ SEOWACKI BY THE PIRAMIDS}

Among the many Polish travellers who visited Egypt in the 19th century, Juliusz Słowacki deserves special attention. He stayed in Egypt from October 20th, 1836, to the end of that year. Słowacki's companion in the travel was Zbigniew Brzozowski, and also, though separately, two brothers and their friends Stefan and Aleksander Hołyński made a trip to that country. All of them, with the exception of the émigré poet, were wealthy landowners.

Słowacki visited Alexandria and Cairo, saw the inside of the Pyramid of Cheops and climbed up its top, as well as up the Nile reached the island of Philae in the South. On his way he took great pleasure in the ruins of temples and pharaohs' tombs. He opposed the profanation of tombs and robbery of Egyptian antiquities done by European art collectors and their agents.

An effect of Słowacki's travel were poetic reflections about the history of Egypt and the monuments of Egypt. The reflections surpass the "Egyptian" pieces by Western poets contemporary to Słowacki, not excluding Ozymandias by Shelley who, after all, never went to Egypt.

Słowacki's notebook from his travel to the East, containing images, notes and poems, has recently been found. A part of Krasiński Library collection, for many years considered as destroyed during the war, the notebook, following many war vicissitudes, reached a library in Moscow and is presently a subject of editorial activities performed by Polish specialists within the framework of the project sponsored by the Polish National Centre for Science (grant nr. NCN 2014/15/B/H52/01360) and directed by professor Maria Kalinowska. 